\title{
EVOLUTION OF IMMUNOBIOLOGICAL CHANGES AND THEIR SIGNIFICANCE FOR THE TREATMENT OF PATIENTS WITH NON-HODGKIN'S LYMPHOMA
}

\author{
Aliona NICORICI ${ }^{1 \otimes}$ \\ ${ }^{1}$ Public Health Institution Institute of Oncology, Chisinau, Republic of Moldova \\ Received 29 Mar 2019, Accepted 15 May 2019 \\ https://doi.org/10.31688/ABMU.2019.54.2.01
}

\section{Abstract}

Introduction. Non-Hodgkin's lymphoma (NHL) shows clonal and uncontrolled proliferation of immature lymphoid precursors.

The aim of the study. Dynamic analysis of immunobiological and immunophenotypic parameters in the treatment of patients with NHL, and recognition of immunological remissions.

Material and methods. The retrospective study group consisted of 122 patients, admitted between 2012 and 2015 in the Hematology Clinic of the Republic of Moldova Oncology Institute, with a morphologically confirmed diagnosis of NHL. We assessed the predominant phenotypic line by indirect immunophenotyping and total concentration of immunoglobulin classes $(A, M, G)$ according to treatment regimens applied to NHL patients.

Results. 119 patients showed CD19 antigen and CD20 increased expression of cell line B phenotype (84.4\%); only 3 patients in the study showed increased CD3, CD5, resulting in the predominant T-cell phenotype line. NHL patients with both aggressive and non-aggressive primary variants after 3 cycles and $6 \mathrm{cy}$ cles presented a significant decrease in immunoglobulin $\mathrm{A}, \mathrm{M}$, and $\mathrm{G}$ indices, on average of $7.3 \pm 0.2(\mathrm{mg} / \mathrm{ml})$ $(p<0.05)$, while the immunological indices of patients treated with the polychemotherapy (PTCH) scheme 2 reported statistically significant minimal decreases $(\mathrm{p}$

\section{Résumé}

Evolution des modifications immunobiologiques et leur importance dans le traitement de patients atteints de lymphome non-Hodgkinien

Introduction. Le lymphome non-Hodgkinien (LNH) montre une prolifération clonale et incontrôlée de précurseurs lymphoïdes immatures.

Le but de l'étude. Analyse dynamique des paramètres immunobiologiques et immunophénotypiques dans le traitement des patients atteints de LNH et reconnaissance des rémissions immunologiques.

Matériel et méthodes. Le groupe d'étude rétrospectif était composé de 122 patients, admis entre 2012 et 2015 à la clinique d'hématologie de l'Institut d'Oncologie de la République de Moldova, avec un diagnostic de LNH confirmé par la morphologie. Nous avons évalué la lignée phénotypique prédominante par immunophénotypage indirect et concentration totale des classes d'immunoglobulines (A, M, G) en fonction des schémas thérapeutiques appliqués aux patients présentant un LNH diagnostiqué.

Résultats. 119 patients ont présenté l'expression accrue de l'antigène CD19 et CD20 du phénotype de la lignée B (84,4\%); seuls 3 patients de l'étude ont présenté une augmentation de CD3, CD5, entraînant la lignée de phénotype prédominant des cellules $\mathrm{T}$ avec un poids de $2,4 \%$. Les patients $\mathrm{LNH}$ avec des variantes 
$<0.05$ ), setting an incomplete immunological remission.

Conclusions. Due to the information obtained by periodic monitoring of patients with NHL following the termination of conventional clinical protocols, it was possible to reveal the immunological and immunophenotypic features of the disease, for the detection of early and late recurrences, late side effects, occurrence of the second malignancy, with the evaluation of the immunological and immunophenotypic remission and identification of specific molecular targets for subsequent targeted therapy.

Keywords: polychemotherapy, non-Hodgkin's lymphoma, target treatment, monoclonal antibodies, immunoglobulins.

\section{List of abbreviations:}

NHL - Non-Hodgkin's lymphoma

$\mathrm{mAb}$ - monoclonal antibodies

PCHT - polychemotherapy

Ig - immunoglobulins primaires agressives et non agressives après 3 cycles et 6 cycles dans tous les groupes de traitement assignés aux schémas thérapeutiques ont noté une diminution significative des indices d'immunoglobuline $\mathrm{A}, \mathrm{M}$ et $\mathrm{G}$ en moyenne de $7,3 \pm 0,2(\mathrm{mg} / \mathrm{ml})(\mathrm{p}<0,05)$, alors que les indices immunologiques des patients traités avec le schéma de polychimiothérapie (PCHT) 2 faisaient état de diminutions minimales statistiquement significatives $(\mathrm{p}<0,05)$, ce qui établissait une rémission immunologique incomplète.

Conclusions. Grâce à la recherche sur le suivi périodique des patients atteints de LNH à la suite de l'arrêt des protocoles cliniques conventionnels, il a été possible de révéler les caractéristiques immunologiques et immunophénotypiques de la maladie lors de la détection de récidives précoces et tardives, d'effets secondaires tardifs, de la survenue d'un deuxième cancer avec l'évaluation de la rémission immunologique et immunophénotypique, pour déclencher l'identification de cibles moléculaires spécifiques, en vue d'une thérapie ciblée ultérieure.

Mots-clés: polychimiothérapie, lymphome non-Hodgkinien, traitement ciblé, anticorps monoclonaux, immunoglobulines.

\section{Liste des abréviations:}

LNH - lymphome non-Hodgkinien

AcMo - anticorps monoclonaux

PCHT - polychimiothérapie

Ig - immunoglobulines

help in the staging and detection of residual minimal disease $\mathrm{e}^{7.9}$.

In addition to its use in diagnosis, immunobiological research can serve as a starting point in the selection of individualized therapy, as well as in the determination of the moment of occurrence and installation of immunological and immunophenotypic remissions ${ }^{10-12}$.

\section{THE AIM OF THE STUDY}

Dynamic analysis of expression of immunobiological and immunophenotypic parameters in NHL patients, before and after treatment, to demonstrate and argue the scientific value of predictive factors in improving the long-term survival rate and the recognition of immunological and immunophenotypic remissions in the choice of treatment methods.

\section{Material ANd Methods}

The retrospective study group consisted of 122 patients, admitted between 2012 and 2015 in 
the Hematology Clinic of the Republic of Moldova Oncology Institute, Chisinau, with a morphologically confirmed diagnosis of NHL. All the patients signed an informed consent. The average age of the patients was 56.5 years; the study group included 58 men and 64 women.

The methods of direct and indirect observation have been used in peripheral blood research since the onset of the disease, following the application of specific therapy with intervals of 3 and 6 specific treatment cycles polychemotherapy, with the evaluation of humoral homeostasis indices, the assessment of the lymphoma phenotype by labeling monoclonal antibody $(\mathrm{mAb})$ lymphocytes using luminescent microscopy in the dark field, comparing them for a deductive analysis.

Through the validated data at repeated hospitalizations, we recorded the influence of the response to the applied treatment, relapses and refractory post-treatment complications.
Indirect immunophenotypic investigation was performed in several steps: collection specimens for research, lymphocyte ring separation step, lymphocyte dilution step, approximate dissolution step, $\mathrm{mAb}$ lymphocyte tagging step, mAb labeled lymphocyte dilution step, fluorescence labeling in lymphocyte stages, visualization of malignant lymphocytes in a dark field and interpretation of the results.

According to the research methodology, immunological evidence has been investigated in patients with NHL, grouped according to treatment regimes applied and morphological types in three study groups, on both cell line B and cell line T (Table 1).

\section{Results}

Of the 122 histopathologically diagnosed NHL patients enrolled in the study and examined by the indirect immunophenotyping method of peripheral blood research by labeling lymphocytes with $\mathrm{mAb}$,

Table 1. Distribution of patients according to PCHT treatment.

\begin{tabular}{|c|c|c|c|}
\hline NHL subtype & NHL patients included in the study & PCHT treatment & Treatment regimens \\
\hline \multirow{2}{*}{$\begin{array}{l}\text { Aggressive LNH (lympho- } \\
\text { blastic) }\end{array}$} & 56 & 1. $\mathrm{CHOP}$ & $\begin{array}{c}\text { Cyclofosfan } \\
\text { Doxorubicin } \\
\text { Oncocin (vincristine) } \\
\text { Prednisolone } \\
\end{array}$ \\
\hline & $\begin{array}{l}12 \text { (determined cell line by immuno- } \\
\text { histochemistry biopsy) }\end{array}$ & 2. R - CHOP & $\begin{array}{c}\text { Rituximab (antiCD20) } \\
\text { Cyclofosfan } \\
\text { Doxorubicin } \\
\text { Oncocin (vincristine) } \\
\text { Prednisolone } \\
\end{array}$ \\
\hline $\begin{array}{c}\text { NHL } \\
\text { nonaggressive } \\
\text { (indolent, pro-inflammatory) }\end{array}$ & 54 & 3. CVLP & $\begin{array}{l}\text { Cyclofosfan } \\
\text { Vinblastine } \\
\text { Leukeran } \\
\text { Prednisolone }\end{array}$ \\
\hline
\end{tabular}

Table $2.100 \%$ malignant cells (B lymphocyte cell line phenotype).

\begin{tabular}{|c|c|c|c|c|c|c|c|c|c|c|c|c|c|c|c|}
\hline \multirow{3}{*}{$\begin{array}{c}\text { No. } \\
\text { patients }\end{array}$} & \multirow{3}{*}{$\%$} & \multicolumn{6}{|c|}{ CD 20} & \multirow{2}{*}{ ci } & \multicolumn{6}{|c|}{ CD 19} & \multirow{2}{*}{ ci } \\
\hline & & \multicolumn{3}{|c|}{ abs. } & \multicolumn{3}{|c|}{$\%$} & & \multicolumn{3}{|c|}{ abs. } & \multicolumn{3}{|c|}{$\%$} & \\
\hline & & $\min$ & med & $\max$ & $\min$ & med & $\max$ & $25.4 \pm$ & $\min$ & med & $\max$ & $\min$ & med & $\max$ & \multirow{2}{*}{$\begin{array}{c}19.8 \pm \\
2.3\end{array}$} \\
\hline 119 & 100 & 13 & 42 & 98 & $11.2 \%$ & $36.2 \%$ & $84.4 \%$ & 0.7 & 9 & 32 & 75 & $7.75 \%$ & $27.58 \%$ & $64.67 \%$ & \\
\hline
\end{tabular}

Table 3. Total IgA, IgM, IgG Assay PCHT Study Group Scheme № 1.

\begin{tabular}{|c|c|c|c|}
\hline \multicolumn{4}{|c|}{ Aggressive NHL (Lymphoblastic)13, 14, 16} \\
\hline & $\begin{array}{c}\text { Primary } \\
\mathrm{M}(m g / m L)\end{array}$ & $\mathrm{M}(\mathrm{mg} / \mathrm{mL}) \pm$ after 3 cycles of PCHT & $\mathrm{M}(\mathrm{mg} / \mathrm{mL}) \pm$ after 6 cycles of PCHT \\
\hline IgA & $1.4 \pm 0.1 \mathrm{mg} / \mathrm{mL}$ & $1.1 \pm 0.02 \mathrm{mg} / \mathrm{mL}$ & $1.0 \pm 0.01 \mathrm{mg} / \mathrm{mL}$ \\
\hline $\operatorname{IgM}$ & $1.6 \pm 0.05 \mathrm{mg} / \mathrm{mL}$ & $1.4 \pm 0.08 \mathrm{mg} / \mathrm{mL}$ & $1.2 \pm 0.06 \mathrm{mg} / \mathrm{mL}$ \\
\hline IgG & $17.5 \pm 0.2 \mathrm{mg} / \mathrm{mL}$ & $16.8 \pm 0.1 \mathrm{mg} / \mathrm{mL}$ & $15.2 \pm 0.1 \mathrm{mg} / \mathrm{mL}$ \\
\hline $\mathrm{p}$ & $<0.05$ & $<0.05$ & $<0.01$ \\
\hline $\mathrm{t}$ & 2.84 & 0.98 & 1.82 \\
\hline
\end{tabular}


Table 4. Results of Ig A, IgM, and IgG according to PCHT treatment scheme $\mathrm{N}^{\circ} 3$ in repeated cycling periods for non-aggressive NHL.

\begin{tabular}{|c|c|c|c|}
\hline \multicolumn{4}{|c|}{ Indolent NHL (prolymphocyte) ${ }^{13,14,16}$} \\
\hline & $\begin{array}{c}\text { Primary } \\
M(m g / m L)\end{array}$ & $\mathrm{M}(\mathrm{mg} / \mathrm{mL}) \pm$ after 3 cycles of PCHT & $\mathrm{M}(\mathrm{mg} / \mathrm{ml}) \pm$ after 6 cycles of PCHT \\
\hline IgA & $1.4 \pm 0.08 \mathrm{mg} / \mathrm{mL}$ & $1.2 \pm 0.04 \mathrm{mg} / \mathrm{mL}$ & $1.1 \pm 0.02 \mathrm{mg} / \mathrm{mL}$ \\
\hline IgM & $1.6 \pm 0.05 \mathrm{mg} / \mathrm{mL}$ & $1.4 \pm 0.08 \mathrm{mg} / \mathrm{mL}$ & $1.2 \pm 0.01 \mathrm{mg} / \mathrm{mL}$ \\
\hline IgG & $19.1 \pm 0.2 \mathrm{mg} / \mathrm{mL}$ & $18.8 \pm 0.2 \mathrm{mg} / \mathrm{mL}$ & $15.6 \pm 0.03 \mathrm{mg} / \mathrm{mL}$ \\
\hline $\mathrm{p}$ & $<0.05$ & $<0.05$ & $<0.05$ \\
\hline $\mathrm{t}$ & 2.34 & 1.22 & 1.96 \\
\hline
\end{tabular}

Table 5. Results of IgA, IgM, IgG according to PCHT treatment scheme $\mathrm{N}^{\circ} 2$ in repeated cycles for NHL B - cell.

\begin{tabular}{|c|c|c|c|}
\hline \multicolumn{4}{|c|}{ NHL B - cell } \\
\hline & $\begin{array}{c}\text { Primary } \\
\mathrm{M}(\mathrm{mg} / \mathrm{mL})\end{array}$ & $\mathrm{M}(\mathrm{mg} / \mathrm{mL}) \pm$ after 3 cycles of PCHT & $M(m g / m L) \pm$ after 6 cycles of PCHT \\
\hline IgA & $2.5 \pm 0.02 \mathrm{mg} / \mathrm{mL}$ & $1.7 \pm 0.02 \mathrm{mg} / \mathrm{mL}$ & $1.9 \pm 0.01 \mathrm{mg} / \mathrm{mL}$ \\
\hline IgM & $1.6 \pm 0.01 \mathrm{mg} / \mathrm{mL}$ & $1.4 \pm 0.04 \mathrm{mg} / \mathrm{mL}$ & $1.4 \pm 0.03 \mathrm{mg} / \mathrm{mL}$ \\
\hline IgG & $12.3 \pm 0.03 \mathrm{mg} / \mathrm{mL}$ & $18.8 \pm 0.2 \mathrm{mg} / \mathrm{mL}$ & $16.7 \pm 1.3 \mathrm{mg} / \mathrm{mL}$ \\
\hline $\mathrm{p}$ & $<0.05$ & $<0.01$ & $<0.05$ \\
\hline $\mathrm{t}$ & 2.36 & 1.08 & 1.98 \\
\hline
\end{tabular}

119 patients showed increased affinity for the CD19, CD20 antigen, expressing the cell line B phenotype (Table 2).

As a result of the immunophenotypic investigation of the same group of NHL patients by labeling lymphocytes with CD3 and CD5 monoclonal antibodies, we determined that only 3 patients had lymphocyte $\mathrm{T}$ phenotype.

Thus, the total concentration of immunoglobulins (Ig): $\operatorname{Ig} A$, IgM and $\operatorname{IgG}$ in the group of patients receiving PCHT according to Scheme 1 follows a downward trend (Table 3).

54 NHL patients had indolent morphological subtypes treated with the PCHT treatment scheme 3 and presented a relatively insignificant decrease in the indices of the Ig A, IgM and IgG (Table 4).

In the 12 patients with B-cell LNH (confirmed by immunohistochemical examination) who received the PCHT scheme 2 (R-CHOP), an insignificant reduction in the immune response was observed (Table 5).

\section{Discussion}

Our study shows that B lymphoid cells have a progressive proliferation tendency, which justifies the inclusion in the treatment of NHL of specific monoclonal antibodies as targeted therapy. The proportion of B cells phenotype, encountered in $84.4 \%$ of patients enrolled in the study, did not differ significantly from the literature (over $90 \%$ of cases with B cells) $)^{11,12}$.
In our study, the T-cell NHL was rare, with a frequency of $2.4 \%$ versus $10 \%$ compared to literature data $^{9,14,17 .}$

Table 3 revealed the dynamics of $\operatorname{IgA}$, IgM and $\mathrm{IgG}$ indices during PCHT in 56 patients treated according to protocol treatment scheme 1 and with repeated control of their values after 3 and 6 PCHT cycles. The results showed a significant decrease in all immunoglobulin indices, both primary and in the dynamics after the $3^{\text {rd }}$ and $6^{\text {th }}$ cure of PCHT.

In patients treated with the $\mathrm{N}^{\circ} 1$ and 3 schemes, significant decreases of the $\operatorname{IgA}$, IgM, IgG classes, both primary and after 3 and 6 cycles of PCHT, have been observed. Thus, primary IgA level was 2.5 \pm 0.02 $\mathrm{mg} / \mathrm{mlL}$, after 3 courses it was $1.7 \pm 0.02 \mathrm{mg} / \mathrm{mlL}$ and after 6 courses it was $1.9 \pm 0.01 \mathrm{mg} / \mathrm{mL}$, primary $\operatorname{IgM}$ was $1.6 \pm 0.01 \mathrm{mg} / \mathrm{mL}$, after 3 cures it was $1.4 \pm 0.04$ $\mathrm{mg} / \mathrm{mL}$, after 6 cures $1.4 \pm 0.03 \mathrm{mg} / \mathrm{mL}$. Primary $\mathrm{IgG}$ was $12.3 \pm 0.03 \mathrm{mg} / \mathrm{mL}$, after 3 courses it was $18.8 \pm 0.2$ $\mathrm{mg} / \mathrm{mL}$, after 6 courses $16.7 \pm 1.3 \mathrm{mg} / \mathrm{mL}$ (Table 4).

The results obtained show that the patients in the PCHT mAb CD20 (MabThera) PCHT group (Table 5) had an attenuation of the statistically significant immune response, where p 0.05 established the occurrence of an incomplete immunological remission.

\section{Conclusions}

- Indirect immunophenotypic complement tests, that allowed us to detect B cell line of NHL by 
labeling lymphocytes with mAb CD20, CD19, revealed a significant number of malignant cells, increased in $84.4 \%$ of the patients, proving that B lymphocytes have a progressive proliferative evolution, motivating inclusion in the treatment of $\mathrm{mAb}$ variants of NHL cells as target therapy.

- CD3 and CD5 immunophenotypic examination in NHL patients determined the predominant T-cell phenotype in only 3 patients (2.4\%), against $10 \%$ in the literature.

- Due to the information obtained by periodic monitoring of patients with NHL following the termination of conventional clinical protocols, it was possible to reveal the immunological and immunophenotypic features of the disease, for the detection of early and late recurrences, late side effects, occurrence of the second malignancy, with the evaluation of the immunological and immunophenotypic remission and identification of specific molecular targets for subsequent targeted therapy.

\section{Compliance with Ethics Requirements:}

„The authors declare no conflict of interest regarding this article"

"The authors declare that all the procedures and experiments of this study respect the ethical standards in the Helsinki Declaration of 1975, as revised in 2008(5), as well as the national law. Informed consent was obtained from all the patients included in the study"

„No funding for this study"

\section{References}

1. Corcimaru I. Hematology. Kishinev, 2007, pg. 252-279.

2. Buruiana S. Clinical, hematological and immunohistochemical aspects of non-Hodgkin lymphocytes from lymphocytes. Infomed. 2016; 2(28):52-58.

3. Kovalchuk LV, Gankovskaya LV, Meshkova R Ya. Clinical immunology and allergology with the basics of general immunology: A textbook for universities. M. GEOTAR-Media, 2012.
4. Calvo K, Mc CoyCS, Stetler-Stevenson M. Flow cytometry immunophenotyping of hematolymphoid neoplasia. Methods Mol Biol. 2011; 699: 295-316.

5. Greer J, Williams M. Non-Hodgkin Lymphoma in Adults. In: Greer J, Foerster J, Rodgers G, Pareskevas F, Glader B, eds. Wintrobe's Clinical Hematology. 12th ed. Philadelphia, PA: Lippincott Williams \& Wilkins, 2009:2144-2194.

6. Marcus R, Sweetenham JW, Williams ME. Lymphoma: pathology, diagnosis and treatment. Cambridge University Press, Cambridge, UK, 2007.

7. Gaza E, Okada CY. Tumor cell lymphocyte-pulsed dendritic cells are more effective than TCR Id Protein vaccines for active immunotherapy of T cell 1 Lymphoma. J Immunol 2009; $169 ; 5227-5235$

8. Rodriquez J, Caballero MD, Gutierrez A, et al. High-dose chemotherapy and autologous stem cell transplantation in peripheral T-cell lymphoma: the Gel-TAMO experience. Ann Oncol. 2003;14(12):1768-1775.

9. Moura IC, Lepelletier Y, Arnulf B, et al. A neutralizing monoclonal antibody (mAb A24) directed against the transferrin receptor induces apoptosis of tumor $\mathrm{T}$ lymphocytes from ATL patients. Blood. 2004; 103(5):1038-1845.

10. Shustov AR, Savage KJ. Does high dose therapy and autologous hematopoietic stem cell transplantation have a role in the primary treatment of peripheral cell lymphomas? Hematology Am Soc Hematol Educ Program; 2008:39-41.

11. Kreitman RJ. Immunotoxins for targeted cancer therapy. AAPS J. 2006;8(3):E532-E551.

12. Bèné M, Kaeda J. How and why minimal residual disease studies are necessary in leukemia: a review from WP10 and WP12 of the European Leukemia Net. Haematologica. 2009;94(8):1135-50.

13. Krivolapov Yu A, Leenman EE. Morphological diagnostics by lymphoma. COSTA, 2006. https://epdf. tips/-b0a5020784a056fc49db0f538fbd26d731335.html

14. Mazurov VI, Krivalopov Yu A. Lymphoma classification, morphology, immunophenotype, molecular genetics by non-Hodgkin's lymphoma. Practical Oncology. 2004;3:169-175.

15. Dzhazhilov AF. Non-Hodgkin's lymphoma - the basis of classification and immunocytochemical diagnosis. Oncology. 2013;15(4):272.

16. Swerdlow SH, Campo E, Harris NL, et al. WHO Classification of tumors of hematopoietic and lymphoid tissues. IARC Press, Lyon, France. $4^{\text {th }}$ edition. 2008.

17. Catana A, Podia Igna C, Deac M. Clinical and histophenotypic aspects in peripheral T-lymphoma on a group of 197 patients in Bucharest. Acta Medica Transilvanica. 2011; 2(3):97-100. 